\title{
Biar Dhanyang yang Bicara: Film Spiritual dan Pesan Substansial dalam Kolaborasi Produksi Film Tetangga
}

Tito Imanda ${ }^{1}$ a)

${ }^{1}$ Badan Perfilman Indonesia

a)imanda@gmail.com

DOl:https://doi.org/10.18196/jkm.101007

\section{Article Info}

Article history:

Received 27Sept 2018

Revised 190kt 2018

Accepted 27Okt2018

\section{ABSTRACT}

This paper explores methods in making sure a film can make a statements to its audience, in this case to talk about true problems: local identities and natural resources, through non-realistic subjects: the spirits of the village. It focuses on film collaboration with a Javanese traditional performance group adapting their work to film. The project has both practical and research goals. The practical goal is to collaborate with a traditional performance from a rural area, and help facilitate their exploration of a new medium to express their narrative, aesthetic and cultural messages through film. On the other hand, using ethnographic methods, the research goal of this project is to record, to understand, and to analyze this process, while laying the groundwork for further collaborations and researches in other contexts and with different communities. What so important is the exploration of the adaptation process of performance arts to film, and how the years of collaboration shapes this process and its products. When we look closely at the aesthetics of the films produced, we observed how they represent the group's and the village's culture, and the members' and the villagers' identities as well as the new set of film aesthetics that emerged from the collaboration.

Keywords: Collaborative Filmmaking;Film Studies;Media Anthropology;

\section{ABSTRAK}

Makalah ini mengeksplorasi cara-cara untuk memastikan sebuah film dapat membuat pernyataan kepada para pendengarnya, dalam hal ini untuk berbicara tentang masalah-masalah yang ada dalam realitas: identitas lokal dan sumber daya alam, melalui tema yang tidak realistis: roh-roh desa. Tulisan ini berfokus pada kolaborasi film dengan kelompok pertunjukan tradisional Jawa, untuk mengadaptasi karya-karya panggungmenjadi karya layar. Proyek ini memiliki tujuan praktis dan riset. Tujuan praktisnya adalah untuk berkolaborasi dengan pertunjukan tradisional dari daerah pedesaan, membantu memfasilitasi eksplorasi mereka terhadap media baru untuk mengekspresikan pesan narasi, estetika dan budaya mereka melalui film. Di sisi lain, dengan menggunakan metode etnografi, tujuan penelitian ini adalah untuk merekam, memahami, dan menganalisis proses ini, sambil meletakkan dasar untuk kolaborasi dan penelitian lebih lanjut dalam konteks lain dan dengan komunitas yang berbeda. Apa yang penting adalah eksplorasi proses adaptasi seni pertunjukan untuk film, dan bagaimana kolaborasi bertahun-tahun membentuk proses ini dan produknya. Ketika kami melihat secara dekat estetika film yang dihasilkan, kami mengamati bagaimana mereka mewakili budaya kelompok dan desa, serta identitas anggota 
dan penduduk desa serta kumpulan estetika film baru yang muncul dari kolaborasi.

Kata kunci : Pembuatan Film Kolaboratif; Kajian Film; Antropologi Media;

\section{Page 176 PENDAHULUAN Memahami Tjipta Boedaja}

Tulisan ini membuat argumen bahwa walau film menampilkan hal-hal yang tidak nyata, dia memiliki kekuatan untuk menggugah pembicaraan mengenai hal-hal yang nyata yang penting untuk dibicarakan. Penelitian ini adalah bagian dari sebuah penelitian etnografi selama sembilan tahun untuk menggali pertanyaan bagaimana kolaborasi membuat film mempengaruhi sebuah kelompok seni pertunjukan tradisional memindahkan estetika dan pernyataan mereka dari panggung ke layar film. Bagaimana pun, tulisan ini fokus ke produksi film yang dilakukan pada tahun 2017, saat para pelaku seni pertunjukan tradisional ini sudah melewati masa adaptasi kepada medium baru dari pengalaman-pengalaman berkolaborasi sebelumnya. Lebih khusus lagi, tulisan ini ingin melihat bagaimana dalam proses menggali kemungkinan pernyataan-pernyataan yang ada dengan memahami kelompok seni itu dan dusun tempat tinggal mereka sendiri menyikapi isu-isu yang terkait dengan identitas, situasi ekonomi-politik, dan kebudayaan.

Dari temuan tahapan-tahapan kolaborasi sebelum sampai ke titik ini, kita tahu bahwa kolaborasi harus menjadi ajang pertukaran. Adaptasi praktik-praktik estetika tertentu ke dalam film membutuhkan bukan hanya seniman lokal yang mempelajari film dan memperoleh pengalaman membuat film, tetapi juga kolaborator dari luar -dan dalam hal ini termasuk saya, pembuat film dari daerah urban- yang juga bersedia untuk belajar mengenai kelompok lokal itu, dusun dan desa mereka, dan kebudayaan mereka.

Kelompok seni tradisional yang menjadi fokus proyek ini adalah Padepokan Tjipta Boedaja, yang terletak di Dusun Tutup Ngisor, Desa Sumber, Kecamatan Dukun, Kabupaten Magelang, Jawa Tengah. Dusun ini terletak di kaki Gunung Merapi, di perbatasan antara Daerah Istimewa Yogyakarta dengan Propinsi Jawa Tengah. Sebagai sebuah masyarakat pertanian yang terletak di kaki gunung aktif, masyarakat Tutup Ngisor banyak menggunakan kesenian bukan dengan tujuan utama mencari nafkah, tapi untuk upacara hasil pertanian dan keselamatan. Tentu saja anggota kelompok ini menerima tanggapan manggung dari warga desa lain, atau acara resmi instansi pemerintah, tapi tidak untuk menjadikan seni sebagai sumber utama pencarian nafkah. Sejak didirikan oleh Yoso Soedarmo pada tahun 1937, padepokan ini mewajibkan seluruh anggotanya untuk bertani, dan melarang menggantungkan hidup pada kegiatan kesenian. Seni adalah hal serius bagi anggota padepokan ini, tapi dibatasi hanya menjadi kegemaran atau hobi, dan karena keseriusan mereka dalam menjalani kesenangan ini, maka kualitas estetika mereka bisa terjaga dan berkembang, serta memungkinkan mereka memiliki posisi independen untuk menyampaikan pesan atau pernyataan bagi penontonnya.

Sikap kritis Tjipta Boedaja di antara lain juga dibentuk oleh interaksi mereka dengan banyak orang: seniman, aktifis dan akademisi. Selain itu, tradisi kesenian yang mereka jalani, khususnya wayang orang yang berasal dari dalam keraton Jawa juga merupakan sebuah kesenian yang menjadi cara raja membuat pernyataan tanpa harus menyatakannya langsung (Soedarsono, 1984, lihat juga Hughes-Freeland, 2008). Dari sini jelas, kegiatan belajar dan memproduksi film bukan medium pertama bagi penari Tjipta Boedaja untuk menjadi kritis, karena mereka telah terbiasa konsisten membuat pernyataan melalui karya-karya tari mereka. Bagaimana pun, para kolaborator sadar bahwa film, sebagai media massa, memberikan mereka kekuatan lebih untuk berkomunikasi, tidak hanya dengan penonton yang hadir di saat pertunjukan, tapi juga yang berada di tempat-tempat jauh dan penonton yang ada di masa depan. Sementara warga Dusun Tutup Ngisor tetap menjadi target utama bagi film-film ini, para seniman ini sadar betul bahwa film memberikan mereka kekuatan untuk berbicara dengan pemirsa yang lebih luas.

Di tahun kesembilan proyek panjang ini, para kolaborator menggali kegelisahan mereka sebagai seniman Tjipta Boedaja dan penduduk dusun Tutup Ngisor, terutama dalam memahami identitas mereka dan menaklukan tantangan-tantangan dalam kehidupan mereka serta situasi dunia yang berubah. Apa yang harus disampaikan kepada diri mereka sendiri dan dunia luar? Eksplorasi dari film yang terakhir diproduksi ini menunjukkan kolaborator dari dalam dan luar dusun dapat memulai ide dari inspirasi sumber masalah yang berbeda dan dan bekerja sama dalam mewujudkan ide ini. 


\section{Menggali Kemungkinan Ekspresi Film}

Dalam pembuatan film-film dalam kolaborasi dengan Tjipta Boedaja sebelumnya, terlihat bahwa hasil-hasil film muncul dalam dua ciri utama: film sebagai atraksi dan film sebagai tuturan cerita. Istilah 'sinema atraksi' (cinema of attraction) yang menekankan karakter film sebagai atraksi tontonan, datang dari ahli film Tom Gunning dari apa yang menurutnya terjadi selama satu dasawarsa pertama sinema, yaitu sejak ditemukan hingga tahun 1906, saat film diperlakukan sebagai alat agar kejadian bisa dilihat ulang. Dia mendefinisikan sinema atraksi sebagai: "sinema yang menampilkan keterlihatannya, bersedia untuk memisahkan diri menjadi dunia khayalan tersendiri untuk kesempatan mendapat perhatian penonton"1 (Gunning, 1990). Sementara itu, film sebagai tuturan (cinema of narration) adalah film yang fokus kepada unsur-unsurnya untuk menceritakan sebuah rangkaian cerita. Film semacam ini mulai terbentuk setelah tahun 1913, setelah transisi dari sinema atraksi yang prosesnya dimulai di tahun 1907 (Keil, 2001). Film yang menjadi fokus pembahasan dari tulisan ini dibuat dengan semangat pertama, yaitu film sebagai atraksi.

Pilihan kepada sinema atraksi muncul karena adanya semangat agar film ini membawa semangat kritis Tjipta Boedaja yang selama ini muncul dalam pertunjukan-pertunjukan panggung mereka. Posisi memahami film sebagai atraksi visual yang memiliki kekuatan untuk menggugah penontonnya, dan istilah ini sendiri, muncul dari temuan Gunning pada tulisan-tulisan lama pembuat film Rusia Sergei Eisenstein yang bersemangat pada kekuatan film untuk melawan kekuatan industri (Gunning, 2006) dan menyebut apa yang Eisenstein lihat dalam pertunjukan teater panggung sebagai atraksi yang memiliki kekuatan psikologis bagi penonton (Gunning, 1990). Ahli film Rachel Moore melangkah lebih jauh dengan menyebut sinema semacam ini memiliki potensi untuk memprovokasi pemikiran penontonnya, menjadikan film sebagai -ini kata-kata Moore sendiri- 'jimat sihir' ('magical fetish') (Moore, 1993), yang memiliki 'kekuatan menyembuhkan' ('curative magic'), dengan kemampuan 'ritual penyembuhan' ('ritual cure') (Moore, 1993). Moore percaya bahwa saat segalanya menjadi semakin mengekang (dalam masyarakat industri), pekerjaan semakin mekanis, kehidupan sehari-hari terasa menjadi rangkaian gangguan yang terpisah, ketimbang kesatuan pengalaman-pengalaman, orang-orang menjadi lelah, teralihkan perhatiannya, dan kehabisan tenaga. ${ }^{2}$ (Moore, 1993). Sinema bisa mengatasi masalah ini dengan memberikan gambar-gambar yang menggugah kesadaran penontonnya.

Moore, yang terilhami oleh pembuat film awal dan grup Frankfurt School yang sudah membahas kekuatan film ini sejak tahun 1920-an, percaya film memiliki kekuatan pisau bermata dua: untuk mengendalikan atau membebaskan penontonnya. Di satu sisi, mengulangi apa yang dulu pernah disampaikan ahli Frankfurt School Sigrid Kracauer, film komersial malah sengaja mengalihkan perhatian penonton dari dunia nyata, dengan memberi penonton gambar-gambar yang menyederhanakan kondisi sebenarnya atau dengan memberikan gambaran yang sama sekali lain dari kehidupan sehari-hari mereka yang menjemukan (Moore, 1993). Di sisi lain, Moore mengulangi semangat pembuat film awal Jean Epstein ketika meyakinkan kita bahwa film dengan kemampuan manipulasinya justru bisa menyadarkan penontonnya bahwa kondisi dunia nyata tidak ideal (Moore,1993). Ahli Frankfurt School lain, Theodor Adorno, menulis di tahun 1966 bahwa penonton film sulit untuk berpikir kritis terhadap film yang ditontonnya karena bentuk fotografi film yang realistis membuatnya diterima mentah-mentah oleh penonton, tanpa dipikirkan. Agar orang mau mengolah apa yang dia tonton dalam pikirannya, seperti halnya penikmat seni melakukannya dalam cabang kesenian lain, Adorno mengusulkan perlu ada penghalang dalam film, yang bisa dibuat dengan efek kamera atau editing, untuk mengurangi realisme obyektif film (Adorno, 1982).

Tarian dalam film-film kolaborasi dengan Tjipta Boedaja, tentu sebetulnya telah mengurangi efek realistis film dengan cukup efektif. Seperti telah diuraikan sebelumnya, tentu saja para seniman Tjipta Boedaja sudah membuat pernyataan dalam film-film mereka sebelumnya, yang membahas masalah keserakahan manusia, pemimpin yang ideal, masalah dalam memelihara tradisi, dan keterbatasan

\footnotetext{
1 "a cinema that displays its visibility, willing to rupture a self-enclosed fictional world for a chance to solicit the attention of the spectator" (Gunning, 1990, p. 57)

2"[a]s things become more powerful [in industrial societies], work more mechanical, and daily life more a series of disrupting noises than assimilable experiences, the person was fatigued, distracted, and exhausted" (Moore, 1993, h. 9)
} 
sumber daya. Dalam tradisi film yang dibuat oleh masyarakat pinggiran, antropolog Faye Ginsburg menyebut karya semacam ini sebagai karya yang 'membantah' ('talking back') (Ginsburg, 2002), atau yang oleh antropolog lain, William Lempert disebut sebagai 'wacana identitas kritis' ("critical identity discourse") (Lempert, 2012). Untuk film ini, para pembuat film pun menggali kemungkinan pernyataan penting yang baru.

Berbeda dengan produksi film-film sebelumnya yang melibatkan pembuat film urban lebih Page 78 banyak, dalam produksi film ini saya merupakan satu-satunya kolaborator produksi asal luar desa. Saat itu, menjelang pertengahan tahun 2017, saya baru saja membaca kembali tulisan akademis dari pengkaji film Fatimah Tobing Rony yang membela spiritualisme penduduk asli dalam hasil penelitian peneliti Barat. Spiritualisme lokal ini biasanya banyak dikurangi, dianggap tidak ada, atau berusaha dijelaskan sebagai sesuatu yang lain oleh rasionalitas peneliti. Hal ini kemudian melahirkan pertanyaan bagi Rony, yang kira-kira berbunyi: 'jika penduduk asli bilang mereka kerasukan, mengapa harus dibilang mengalami gangguan kejiwaan?' (Rony, 2006). Saya mengajukan ide membuat film mengenai kehidupan spiritual masyarakat Tutup Ngisor, terutama untuk melawan anggapan bahwa aktivitas ini mempersekutukan Tuhan, dan gagasan ini disambut oleh para kolaborator lokal. Kami lalu mengembangkan ide berdasarkan tradisi tugas bagi anak-anak Tutup Ngisor untuk mendistribusikan sajen atau sesajen (sajian untuk mahluk halus) ke kurang lebih tiga puluh titik di dalam dan sekitar dusun pada saat perayaan Suran atau tahun baru Jawa. Penduduk lokal percaya bahwa ketiga puluh titik ini -sebuah batu besar di tengah kampung, pohon-pohon, patungpatung, mata air, struktur bendungan, dan lain-lain- menjadi tempat tinggal mahluk spiritual yang memiliki berbagai karakter dan fungsinya. Dengan memberikan tugas ini kepada anak-anak, terlihat bahwa penduduk dusun ingin memelihara tradisi ini hidup hingga ke masa yang akan datang.Pada kenyataannya, di saat ini pun, hanya sedikit warga dusun yang mengetahui detail kegunaan dan mekanisme dari kegiatan tersebut. Ada dua catatan yang paling penting, yang pertama adalah pemberian sajian ini adalah usaha dari warga desa untuk hidup selaras dengan dunia spiritual dan alam semesta: pengiriman makanan ini sama fungsinya dengan mengirim makanan ke tetangga. Catatan kedua adalah mahluk-mahluk ini lekat dengan situasi alamiah di sekitar dusun; keinginan untuk hidup serasi dengan mahluk-mahluk ini sama dengan menjaga kebutuhan untuk hidup selaras dengan kelestarian alamiah di sekitar dusun.

Film ini mengangkat tradisi mistis di Tutup Ngisor. Walau jarang muncul sebagai topik pembicaraan dengan saya atau ketika saya berada di sana, dan sementara mereka sangat rasional dan kosmopolit, para penari dan para penduduk dusun sangat bangga kepada tradisi Jawa mereka, sebuah perpaduan sinkretis antara animisme, ajaran Hindu, dan ajaran Islam. Salah satu hal penting adalah para penduduk dusun percaya bahwa mahluk-mahluk mistis ini hidup bersama kita, dan mereka berharap bisa hidup serasi bersama mereka. Mahluk-mahluk ini tidak harus berbentuk hantu yang menakutkan, seperti bagaimana produk-produk kesenian popular memberi bentuk pada mereka, mereka bahkan bisa saling menolong dalam kehidupan sehari-hari dengan manusia. Hal ini biasa kita temukan dalam komunitas-komunitas di sekitar Merapi, seperti ditunjukkan dalam karya antropologi(Triyoga,2010). Di Tutup Ngisor kepercayaan ini dirayakan dengan beberapa upacara pada saat festival. Ada buku-buku panduan yang membantu orang Jawa yang memegang tradisi semacam ini, dan beberapa orang, biasanya orang-orang tertua di kampung, bertanggung jawab untuk menafsirkan buku ini sesuai dengan pengalaman mereka. Orang-orang ini menjadi sumber penting dalam riset mempersiapkan film ini.

Kembali ke saat para kolaborator membicarakan bagaimana agar ide ini dapat bertransformasi untuk kepentingan Tjipta Boedaja dan Tutup Ngisor. Semua setuju bahwa pesan ini penting untuk mempertahankan nilai dan pengetahuan penduduk dusun sendiri terkait proses mendistribusikan sesajen, terutama bagi generasi muda. Lebih jauh lagi, kolaborator juga membicarakan tuduhantuduhan bahwa memberikan sesajen merupakan hal syirik, menjauhkan orang dari ajaran agama, dan mengancam keberadaan Tuhan. Para kolaborator membentuk film ini untuk mengkonfrontasi tuduhan-tuduhan ini dan menekankan fungsi pendistribusikan sesajen untuk dusun itu: menjaga harmoni dengan lingkungan sekitar. Untuk memastikan film ini mencapai tujuannya, tantangan terbesar film ini adalah menunjukkan mahluk-mahluk ini secara visual sedemikian rupa hingga bisa membuat penonton lokal merasa terhubung. Sementara itu, untuk memperbesar kemungkinan penonton dari luar Tutup Ngisor bisa memahami maksud film ini, para pembuat merencanakan film ini menunjukkan harmoni antara manusia dengan lingkungannya, sebagai manfaat dari aktivitas peletakan sesajen ini. Isi film pun direncanakan. Film ini akan dimulai menggambarkan anak-anak meletakkan sesajen, diikuti oleh kemunculan para mahluk ini untuk menyantap sesajian dan menari, 
Vol. 10 No. 2

November 2018

menggambarkan kesenangan mereka mendapat kiriman makanan. Narasi atau plot hampir tidak ada, dan film ini direncanakan untuk banyak bergantung pada gambar untuk menyampaikan pesannya. Saat itu pun diputuskan judul film: Tetangga. Tahap pra-produksi mulai dari perencanaan ini, pengumpulan data berupa wawancara dengan para tetua desa dan siapa saja yang mengaku pernah melihat, mendengar, merasakan, atau berinteraksi dalam cara apa pun dengan mahluk-mahluk ini. Pertanyaan yang dikumpulkan jawabannya adalah proses ritual pengiriman sesajen ini di Tutup Ngisor sendiri -yang sebetulnya sudah banyak didokumentasikan dengan kamera video oleh para kolaborator- tempat-tempat meletakkan sesajian ini, serta ciri-ciri mahluk-mahluk supernatural yang hidup di sana: seperti apa bentuknya, karakternya, tugasnya, ditambah jika ada testimonial apa pun mengenai mereka. Proyek ini mencakup banyak orang sebagai narasumber, dan ini sebetulnya bentuk kolaborasi yang agak baru.

\section{METODE PENELITIAN}

Proyek ini adalah campuran dari cabang ilmu kesenian dan ilmu sosial, atau tepatnya campuran antara kajian film, produksi film, kajian media, dan antropologi. Di dalam data yang dikumpulkan, tentunya ada sisi kesenian berupa data-data produksi film maupun film yang telah selesai dan siap untuk dianalisis sebagai representasi pembuat dan masyarakat penontonnya; karena mereka melihat makna yang khas di dalam film-film itu (Turner, 1988). Walau begitu, metode etnografi menjadi metode utama yang memahami proses kolaborasi, menjadi ujung tombak penelitian ini. Metode ini akan memperhatikan para anggota Padepokan Tjipta Boedaja dan masyarakat Kampung Tutup Ngisor sebagai subyek utama penelitian, mengamati dan merefleksikan pengalaman membuat film bersama, dan merefleksikan atau merenungkan kembali apa yang dialami oleh kolaborator dari kota. Ahli kajian media David Morley menekankan pentingnya etnografi, terutama darisisi refleksif dalam etnografi yang menuntut peneliti untuk selalu berbagi sudut pandang mereka kepada para subyek penelitiandan lalu dengan pembaca karyanya (Morley, 2007). Morley mengingatkan bahwa pendekatan etnografi mengharapkan setiap penelitinya ntuk bersikap "sebagai pribadi, pada level yang manusiawi" ("as a person, at a human level"). Pada waktu tinggal dan hidup bersama dengan masyarakat yang diteliti, sangat penting untuk memastikan bahwa para subyek penelitian percaya bahwa para peneliti datang dengan niat baik dan terlibat dalam hubungan timbal balik, ketimbang hubungan yang eksploitatif dengan mereka (Morley, 2007).

Penelitian ini juga bersifat kolaboratif. Dalam bukunya Creative Collaborations, Vera JohnSteiner mendefinisikan kolaborasi intelektual dan artistic sebagai "para pemikir yang saling tergantung dalam usaha bersama membentuk pengetahuan baru"("the interdependence of thinkers in the co-construction of knowledge") (John-Steiner, 2000),yang (kedua pihak) harus memiliki visi dan tujuan yang sama (John-Steiner, 2000). Sementara itu, antropolog Carolin Fluehr-Lobban mengingatkan bahwa penelitian kolaboratifmelibatkan subyek penelitian secara aktif dalam proses kajiannya (2008).Hal lain yang menjadi sangat penting adalah penelitian kolaborasi dalam ilmu sosial harus dibangun untuk kepentingan subyek penelitian (Rappaport, 2008, h. 2), berdasarkan keinginan untuk mendengarkan suara yang tak terdengar dan memahami kelompok dengan kekuatan sosial yang lebih lemah daripada kekuatan sosial si peneliti (Ortner, 2013). 


\section{PEMBAHASAN}

\section{Kolaborasi Produksi Film Tetangga}

Kemudian, yang perlu diuraikan adalah kolaborasi itu sendiri. Pada bagian awal memulai proses kolaborasi, delapan tahun sebelum pembuatan film ini, kebutuhan awalnya adalah membangun

Page | 80 hubungan, kepercayaan, dan kemampuan untuk melakukan refleksi diri sendiri. Kolaborator yang terlibat harus bisa terbuka mengenai motivasi, tujuan, dan resiko yang dihadapi. Bagian yang dijelaskan dalam tulisan ini berada pada masa-masa semua tahapan ini sudah selesai, dan fokus pada bagaimana para kolaborator, yang telah belajar dari produksi dan kolaborasi sebelumnya, bekerja sama untuk menyelesaikan film yang lebih memuaskan hasilnya. Seharusnya sudah ada pencapaian atau eksplorasi ke arah baru dalam membangun kepercayaan dan membagikan otoritas kerja, mengelola alur gagasan, menjembatani prosedur-prosedur yang bertentangan, dan berbagi tanggung jawab dalam proyek-proyek terakhir ini. Pencapaian terbesar dari tahap ini mungkin adalah kenyataan bahwa para seniman Tjipta Boedaja percaya diri untuk mengerjakan proses ini tanpa dukungan yang besar dari pembuat film urban. Mereka berpikir bahwa pengalaman mereka sebelumnya sudah cukup bagi mereka untuk mulai membuat film-film mereka sendiri. Kali ini, memang saya menjadi sutradara dan salah satu produser dari film Tetangga, tapi selain seorang penari dan seorang ilustrator dari Yogyakarta (yang terakhir bertugas membantu merumuskan bentuk visual mahluk-mahluk yang diperankan ini), saya adalah satu-satunya kolaborator urban dalam produksi ini.

Produksi film Tetangga sebetulnya berskala kecil. Durasi direncanakan hanya berkisar sepuluh menit saja, dan pengambilan gambar dilakukan hanya dalam dua hari. Sebelum suting dimulai, saya membayangkan pengambilan gambar-gambar dilakukan oleh kru sejumlah lima orang. Karena isi film hanya menggunakan beberapa karakter dan tidak memiliki narasi spesifik, seharusnya produksi film ini tidak terlalu berat. Ketika saya mulai menceritakan ide awal ini kepada Saparno, salah satu penari lokal yang kelak menjadi kolaborator utama dalam produksi film ini, dia langsung menawarkan diri untuk bertanggung jawab menata kamera. Saya juga berharap dia dan Widyo Sumpena, anggota Tjipta Boedaja yang lain, untuk bersama saya menjadi produser dalam film ini. Saparno menyanggupi, dan dia menyarankan Setiyoko, penari lain, untuk menjadi manajer properti. Kami juga mengajak Bambang Trisantoso, salah satu penari senior untuk menjadi konsultan tata busana. Saparno meminta sorang koreografer khusus, dan dia memilih Surawan untuk melakukannya. Pada situasi pengambilan gambar sebenarnya nanti, penari-penari lokal yang mendapatkan peran merencanakan koreografi tarian mereka sendiri, dan Surawan pada akhirnya hanya bertanggung jawab merancang koreografi tari bagi satu karakter yang dimainkan oleh seorang penari asal Yogyakarta.

Setelah pembagian tugas, kami mulai proses wawancara dan pengumpulan data. Kami pun bertemu dengan Cipto Miharso, salah satu tetua desa dan salah satu penafsir primbon di Tutup Ngisor, yang juga salah satu anak tertua yang masih hidup dari pendiri padepokan. Kami juga mengundang seorang illustrator dari Yogyakarta untuk hadir pada saat wawancara, untuk menggambar karakterkarakter yang digambarkan oleh Miharso. Kami mengadakan tiga wawancara dengan Miharso, dan kadang Saparno yang hadir masih mengkonfirmasi jawaban Miharso jika ada yang kurang meyakinkan. Dia menggambarkan beberapa mahluk dalam bentuk manusia dan kami selesai wawancara dengan sekitar sepuluh gambar sketsa, walau ternyata tidak dari semua mahluk yang digambarkan itu mendapat sesajen pada saat perayaan Suran, dan tidak semua titik yang diberikan sesajen pada saat Suran dihuni oleh penunggu berbentuk manusia. Kami lalu memutuskan untuk fokus pada titik-titik yang mendapat sesajen pada saat upacara suran saja dan hanya membuat film tentang mahluk-mahluk yang berbentuk manusia saja, yang akhirnya menyisakan tiga titik dan lima karakter. 
Kami lalu menominasikan para aktor dan penari untuk memerankan para karakter ini. Sementara sketsa-sketsa ni secara mengejutkan tampak sangat mirip dengan para penari dan warga dusun Tutup Ngisor, kami memutuskan untuk tidak memilih pemeran berdasarkan kesamaan bentuk fisik dengan gambar-gambar ini, naumun terutama memilih berdasarkan visi kami tentang jenis tarian yang akan dilakukan setiap karakter dan kemampuan penari yang tersedia. Dengan cepat kami setuju untuk memberikan peran Kiyai Jafar, seorang jin Muslim yang tinggal di atas bendungan lahar dingin di sungai di belakang Dusun Tutup Ngisor kepada Markayun, seorang penari yang memiliki lahan garapan di atas bendungan itu. Orang-orang Tutup Ngisor percaya bahwa Kiyai Jafar memiliki masjid besar di atas bendungan dan dia hidup di sana berdua dengan ayam piaraannya. Kadang-kadang orang mendengar suaranya meneriaki petani yang tidak pulang di waktu sholat. Kadang-kadang juga, orang mendengar adzan di sekitar bendungan, dan yakin bahwa itu suara Kiyai Jafar. Sementara itu, kami menganggap penari lain, Untung Pribadi, cocok memerankan Den Bagus Pitono, pengatur energi supernatural yang mengalir di kampung itu. Kami tidak bisa menemukan penari perempuan yang cocok untuk menjadi dua pendampingnya. Masalah kurangnya penari perempuan yang cocok ini juga muncul di dalam usaha mencari pemeran Satariyah, peri cantik pemarah yang menjaga mata air dekat sungai. Karakter-karakter perempuan ini menjadi problematis karena spesifikasi yang diharapkan, dan kebetulan penari perempuan Tjipta Boedaja pada saat ini tidak ada yang sesuai dengan kebutuhan ini. Pendamping Den Bagus Pitono adalah perempuan kembar, sementara gerakan menari Satariyah digambarkan "mirip tari balet".Sulit membayangkan ada penari desa yang bisa melakukan gerakan balet dengan benar.

Sejak awal, Saparno meminta saya untuk mencari penari perempuan dari luar, sementara saya yang berharap film ini menjadi bagian dari ritual Tutup Ngisor merasa penari dari luar akan mengurangi nilai kesakralan film ini. Pada akhirnya, tentu saja persyaratan yang tinggi ini sulit dipenuhi oleh penari perempuan asal Tutup Ngisor, dan akhirnya kami menunjuk dua orang penari perempuan dari kampung sebelah yang secara fisik mirip untuk menjadi pendamping Den Bagus Pitono. Sementara itu, peran Satariyah pada akhirnya kami berikan kepada Luvita Sari, seorang penari lulusan Institut Seni Indonesia Yogyakarta. Di titik ini masalah baru muncul: saya membayangkan para penari mengeksplorasi gerakan tari di lokasi pada waktu luang mereka. Dengan penari-penari dari luar Tutup Ngisor, proses eksplorasi ini mungkin baru bisa terjadi menjelang saat pengambilan gambar atau setidaknya -jika memungkinkan- beberapa hari menjelang pengambilan gambar dimulai. Masalah lain adalah masalah yang manusiawi: semua pemeran sebetulnya punya kekhawatiran jika mereka melakukan kesalahan dalam memerankan karakter yang dilakukan di lokasi tempat tinggal karakter tersebut. Tentu saja, untuk hal ini, kami tidak punya jalan keluar lain selain menyemangati mereka untuk mengeksplorasi gerakan dan mungkin melakukan meditasi di lokasi, sebelum saat pengambilan gambar.

Saparno bertugas sebagai director of photography atau DP. Kami melakukan pengambilan gambar dengan dua kamera digital single-lens reflex (DSLR). Jika pengambilan gambar dilakukan dengan tim yang lebih besar, seharusnya kami memiliki dua operator kamera, namun karena kami memutuskan akan menggunakan tim kecil, Saparno dan saya masing-masing harus menjadi operator kamera. Dalam saat pra-produksi, saya menjelaskan kepada Saparno visi yang saya inginkan sebagai sutradara, dan kemudian pada saat suting dia menjadi bos saya, mengatur-atur teknis sesuai yang diinginkannya berdasarkan visi saya sebagai sutradara. Kami biasa berkumpul di rumah Trisantoso, yang membuka sebuah warung kopi. Saparno dan saya juga berdiskusi panjang lebar mengenai pilihan warna dalam kemungkinan kombinasi warna yang tersedia selama pra-produksi, mempertimbangkan pilihan yang berbeda dari contoh-contoh kombinasi warna yang bisa kami unduh dari internet. Sehari sebelum suting, kami mencoba mengambil gambar-gambar di lokasi dan membandingkan hasilnya dengan kombinasi warna yang telah kami pilih, hingga pada akhirnya kami puas dengan hasilnya. 
Sementara itu, sehari sebelum suting Trisantoso secara tiba-tiba meminta sebuah adegan Satariyah diambil di jembatan gantung yang saat itu baru diresmikan di belakang rumahnya, pada saat menjelang matahari terbenam. Trisantoso adaalah salah seorang penari senior, salah satu anak dari pendiri padepokan Tjipta Boedaja, dan karenanya dia juga merupakan salah satu produser eksekutif dalam produksi ini. Tidak ada yang menyatakan keberatan pada permintaan ini, dan tidak ada yang Page|82 mempertanyakan alasannya meminta tambahan adegan ini. Segera, setelah produksi selesai, Trisantoso menceritakan bahwa dia pernah melihat Satariyah menari gembira di jembatan baru itu, pada saat matahari terbenam. Tapi ada konsekuensi lain dari improvisasi produksi ini: pada hari pengambilan gambar, Sumpeno memajukan jadwal satu jam lebih awal untuk memastikan kami punya cukup waktu untuk menyiapkan adegan saat matahari terbenam. Hasilnya di luar dugaan, karena jatuhnya cahaya matahari di sela-sela rimbunnya daun menjadi sangat berbeda dengan apa yang kami dapatkan sehari sebelumnya. Tak ada lagi yang bisa kami perbuat, sayangnya, dan kami harus tetap melanjutkan pekerjaan dengan komposisi warna yang baru.

Sementara Markayun dan Pribadi telah mengeksplorasi gerakan tari mereka di lokasi-lokasi pengambilan gambar secara langsung, Surawan baru bisa bekerja dengan Luvita Sari untuk menemukan gerakan tariannya pada hari terakhir sebelum pengambilan gambar. Seperti yang saya takutkan, waktunya tidak cukup dan bahkan ketika kami mulai pengambilan gambar bisa terlihat bahwa Sari masih mengeksplorasi gerakan yang dirasanya paling cocok. Keadaan semakin membaik seiring waktu berjalan, namun alur gerakannya pada setiap ambilan gambar (take) belum stabil. Hal ini akan menyulitkan proses penyuntingan gambar nanti.

Saparno kemudian meminta untuk menjadi editor film ini serta mengarahkan komposer gamelan, dan saya memenuhi permintaannya dengan senang hati. Kami membuat diskusi yang kemudian saya ulangi dan saya rekam pada akhir bulan September 2017. Semua pihak merasa kesederhanaan pengaturan dan perencanaan membuat pekerjaan kami relatif mudah dan kami tidak mengulangi kesalahan-kesalahan yang pernah dilakukan sebelumnya. Bagaimana pun, tentu produksi ini masih memiliki banyak kekurangan: kurangnya persiapan koreografi dan tarian-tarian yang dilakukan sepenuhnya dengan improvisasi, menimbulkan kesulitan pada saat penyuntingan gambar sertapembuatan musik pengiring tari setelah pengambilan gambar selesai. Saparno menjelaskan bahwa dengan gerakan tari semacam ini dia harus meminta komposer musik untuk membuat musik yang monoton. Sementara itu, secara kolaborasi, baik Saparno maupun Setiyoko merasa bahwa kami telah mendapatkan ritme kerja yang lebih baik dan berguna untuk persiapan kolaborasi produksi selanjutnya.

\section{Estetika Film Tetangga}

Bagian ini mendiskusikan estetika film Tetangga. Jika kita melihat ke belakang pada film-film yang telah diproduksi dalam kolaborasi ini, maka kita bisa saksikan ada film-film yang memilih gaya sinema atraksi dan ada yang memilih gaya sinema narasi. Cukup jelas bahwa Tetangga memilih gaya sinema atraksi. Bagian yang menarik adalah film-film yang diproduksi dengan gaya sinema atraksi sebelumnya selalu disutradarai oleh penari senior, yaitu Sitras Anjilin yang juga pemimpin Tjipta Boedaja serta anak bungsu dari pendiri padepokan tersebut, sementara penari-penari muda cenderung memilih gaya sinema narasi. Film Tetangga dibuat dengan keterlibatan hampir seluruh kolaboratornya penari muda, dengan satu pengecualian Trisantoso, kakak Sitras Anjilin yang menjadi konsultan kostum serta eksekutif produser film ini. Tidak ada keberatan dan kesulitan apa pun yang muncul dari komposisi usia muda para kolaborator ini. Tetangga tidak memiliki dialog dan narasi linear selain hubungan kausal antara proses peletakan sesajen dan kemunculan para mahluk halus. Untuk membuat film ini menggugah perasaan ritual dari penonton lokal, film ini mengandalkan gambar-gambar yang diharapkan bisa terhubung dengan emosi penduduk Tutup Ngisor. Kami cukup percaya bahwa gambar-gambar yang secara spesifik menggambarkan lokasi yang familiar dengan warga kampung, misalnya, cukup mampu membawa pikiran penonton lokal masuk ke dalam isi film. Ada empat 
Vol. 10 No. 2

November 2018

adegan di lokasi yang berbeda yang menjadi lokasi tinggalnya para dhanyang. Walau lokasi pengambilan gambarnya otentik, namun kesalahan pengambilan gambar atau pengaturan artistik bisa membuat mereka tidak dikenali oleh penduduk lokal.

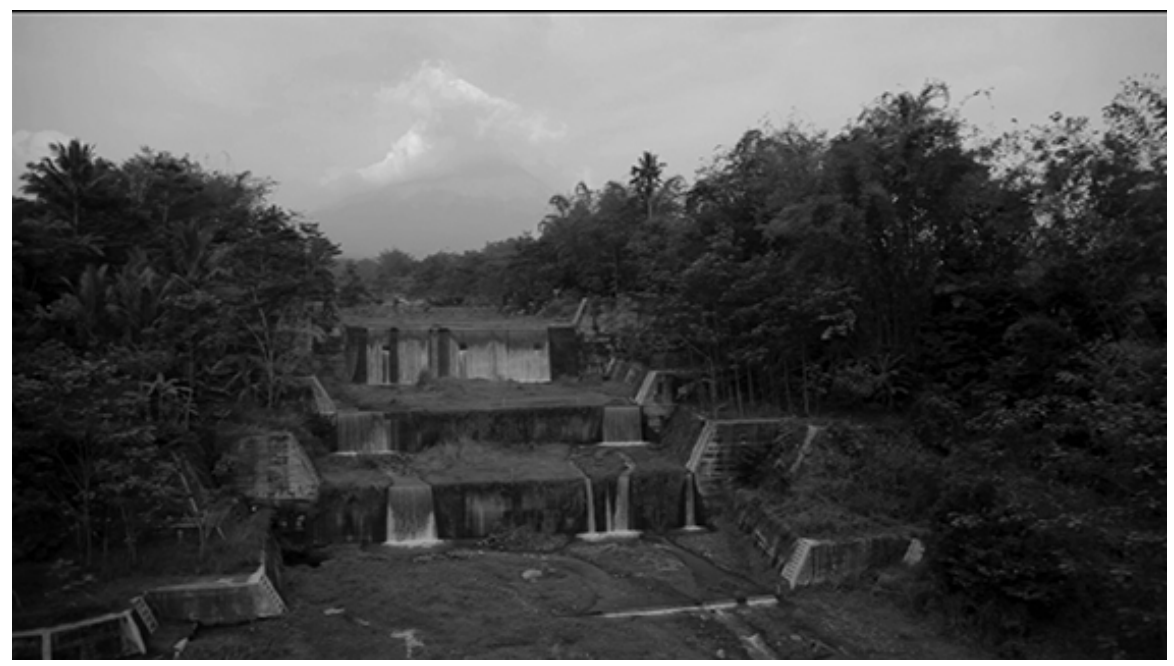

Gambar 1. Pemandangan bendungan membantu penonton lokal mengidentifikasi lokasi.

Bagaimana pun, penampilan dari para pemeran mahluk-mahluk halus ini adalah cerita yang sama sekali berbeda. Sebagaimana terlihat dari saat wawancara dengan tetua kampung, banyak pertanyaan-pertanyaan yang datang dari penari-penari muda Tutup Ngisor sendiri, menunjukkan bahwa memang warga kampung tidak mengetahui banyak soal rincian di balik kegiatan menyebarkan sesajen ini.Film ini harus memberikan cukup petunjuk yang mudah dimaknai oleh penduduk Tutup Ngisor. Bagaimana mahluk-mahluk in berpakaian, bergerak, bersikap, dan menari harus menjadi petunjuk bagi warga Tutup Ngisor. Beberapa gambar dan akting dibuat agar dekat dengan imajinasi morang Tutup Ngisor. Sementara itu, bagian anak-anak berjalan untuk meletakkan sesajen adalah bagian yang pasti akrab di mata para penonton lokal, dan diharapkan adegan-adegan ini cukup untuk memberikan konteks cerita film ini.

Seluruh adegan luar ruangan diambil di lokasi yang menjadi daerah yang dianggap ditinggali mahluk-mahluk ini. Latar belakang setiap adegan direncanakan secara hati-hati, terutama untuk menunjang komposisi warna yang diinginkan sebelumnya. Semua lokasi suting berada di tempattempat yang tersedia di sekitar kampung, seperti bendungan dan mata air, yang sudah terasa akrabbagi penonton, tapi dalam film ini mereka semua harus terlihat lebih mistis. Seperti diceritakan sebelumnya, sebetulnya penataan warna dalam film sudahdirancang untuk memenuhi kebutuhan ini, namun jadwal pengambilan gambar hari pertama yang maju satu jam lebih cepat dari perencanaan sebelumnya membuat hasil agak berbeda dari yang direncanakan. Cahaya dalam film yang diambil menjadi lebih terang dan datang dari arah yang lebih tinggi, memberikan banyak bayangan jatuh, yang gelapnya kontras dengan aktor dan benda-benda yang ada di layar terlihat sangat terang. Di titik ini, kami memutuskan untuk beriomprovisasi dengan memaksimalkan efek mistis dari sebelumnya menangkap cahaya mendung yang remang-remang menjadi menangkap cahaya matahari yang lolos di antara bayangan dedaunan. 


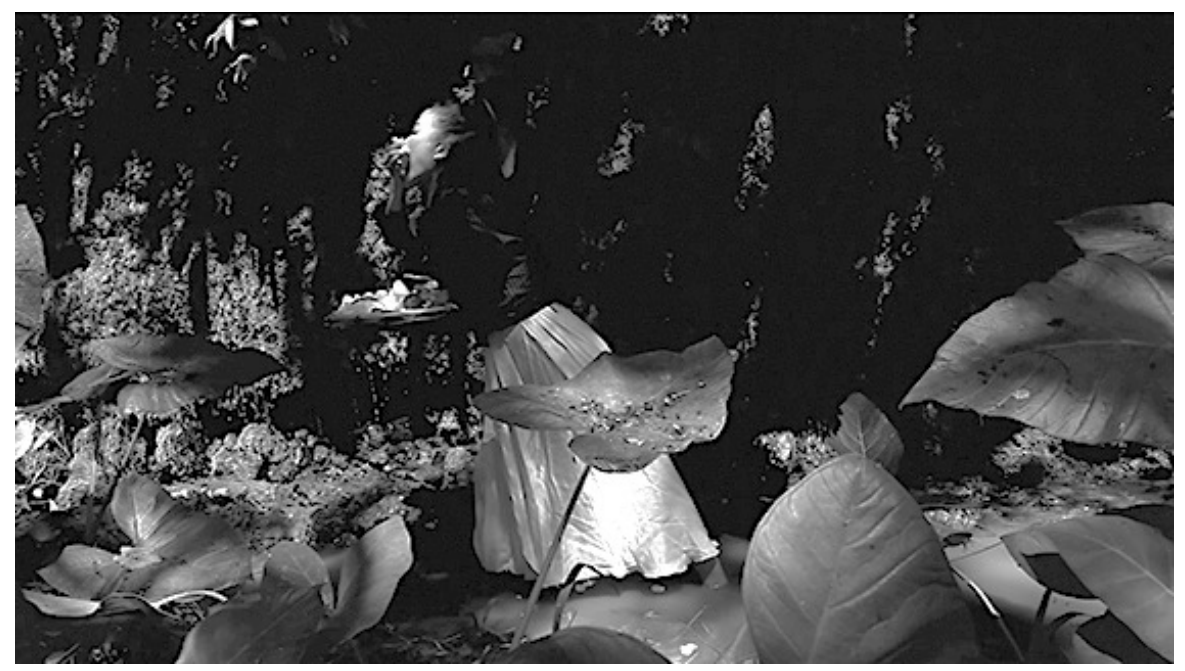

Gambar 2. Perhatikan cahaya matahari yang pecah di daun dan cara peri Satariyah bersemangat makan sesajen, menggambarkan kepribadiannya

Semua karakter secara umum menggunakan tata rias natural. Kostum dibuat sedekat mungkin dengan tuturan Miharso. Bagaimana pun, para kolaborator menghabiskan waktu berjam-jam mendiskusikan bahan, motif batik, serta warna, dan dalam kasus ini, meyakinkan bahwa mereka serasi dengan keputusan komposisi warna yang telah didiskusikan sebelumnya. Karenanya, kostum dalam film Tetangga lebih terkordinasi warnanya daripada film-film sebelumnya.

Dalam penampilan tarian,Tetangga memiliki beberapa masalah yang belum bisa melepaskan diri dari masalah lamanya: kekurangan waktu untuk menyiapkan koreografi terinci untuk layar. Karena film ini akan benar-benar menjadi film tari utuh tanpa dialog dan dengan akting sehari-hari yang minimum, selain karakter anak-anak mengantar sesajen, hampir seluruh penampilan dalam film ini muncul dalam bentuk tari. Pengaturan dilakukan dengan benar, kami membuat para penari mengeksplorasi gerakan mereka di lokasi, kami menyiapkan koreografer khusus bagi penari asal luar Tutup Ngisor, dan kami menjelaskan kepada aktor-aktor luar ini mengenai konteks-konteks mahluk halus dan latar kebudayaan di Tjipta Boedaja dan Tutup Ngisor. Kami juga membiarkan mereka menggali kemungkinan gerakan hingga saat pengambilan gambar dimulai. Namun tetap saja, tarian mereka masih berdasarkan improvisasi dan pada setiap pengambilan gambar gerakan mereka berbeda. Nantinya ini akan membuat hidup Saparno sebagai editor agak sulit. Selain itu, dari pangalaman sebelumnya, seharusnya kami menyiapkan koreografer untuk membuat gerakan tarian yang memiliki naratif, dengan mempertimbangkan perencanaan pengambilan gambar dengan kamera.

Masalah koreografi ini sebetulnya tertutup oleh tata sinematografi yang direncanakan oleh Saparno. Dua kamera mengeksplorasi detail dari gerakan dan pemandangan melalui berbagai tipe arah dan ukuran pengambilan gambar serta beberapa gerakan kamera, menghasilkan persediaan bahan edit yang cukup banyak dan bervariasi. Walaupun, semua pengambilan itu dilakukan tanpa storyboard dan perencanaan yang matang. Penata kamera yang bekerja sama secara detail di saat perencanaan dengan koreografer dan penari belum bisa terwujud secara maksimal dalam kolaborasi in,dalam menghasilkan apa yang disebut sebagai usaha film tari untuk memindahkan kualitas keindahan ketubuhan yang sulit dijelaskan dari tarian ke dalam layar ("elusive and corporeal quality of dance into the screen") (Brannigan,2011, hh. 8--9). Dalam film ini, dengan merekam sebanyakbanyaknya pengambilan gambar, kami berharap proses editing dapat memilih gambar yang paling tepat dan, mudah-mudahan, terlihat seperti dalam urutan koreografi yang jelas.

Saparno bekerja sebagai editor. Dia masih dalam proses belajar menyunting film dan belajar berbagai perangkat lunak editor di komputer. Dia menggunakan perangkat profesional, namun 
Vol. 10 No. 2

November 2018

laptopnya bukan yang cukup kuat untuk menjalankan perangkat ini secara maksimal, sehingga kita bisa melihat beberapa kerusakan gambar di dalam hasil penyuntingannya. Pada akhirnya Saparno juga masih terlihat membutuhkan pengetahuan dasar pasca produksi: koreksi warna, pengeditan suara, dan penambahan efek-efek yang diperlukan. Secara umum, menurut saya dia telah membuat pekerjaan editing yang tidak buruk, dan dengan bertambahnya pengalaman, hasil pekerjaannya akan membaik. UntukTetangga, walau urutan dalam tarian dan adegan cukup jelas, proses pengeditan berlangsung seperti mengedit film etnografi yang harus mengumpulkan bahan gambar sebanyak-banyaknya, menontonnya berulang-ulang untuk menentukan urutan yang pas, lalu meletakkannya dalam garis waktu dan lalu mengurangi atau menghilangkan bagian-bagian gambar yang paling tidak diperlukan, hingga film dapat mengalir dengan mulus.

Salah satu catatan tambahan dari Trisantoso adalah bagaimana bisa melibatkan komposer musik sejak awal: proses kali ini yang baru melibatkan perancang musik masuk setelah pengambilan gambar selesai membutuhkan waktu yang lebih banyak baginya merenungkan kebutuhan film ini, yang seharusnya jika dia dilibatkan sejak awal bisa membuat proses berlangsung lebih cepat. Bagi Trisantoso, pembuatan film adalah pekerjaan yang banyak membutuhkan perenungan, dan setiap posisi harus terlibat secara mendalam.

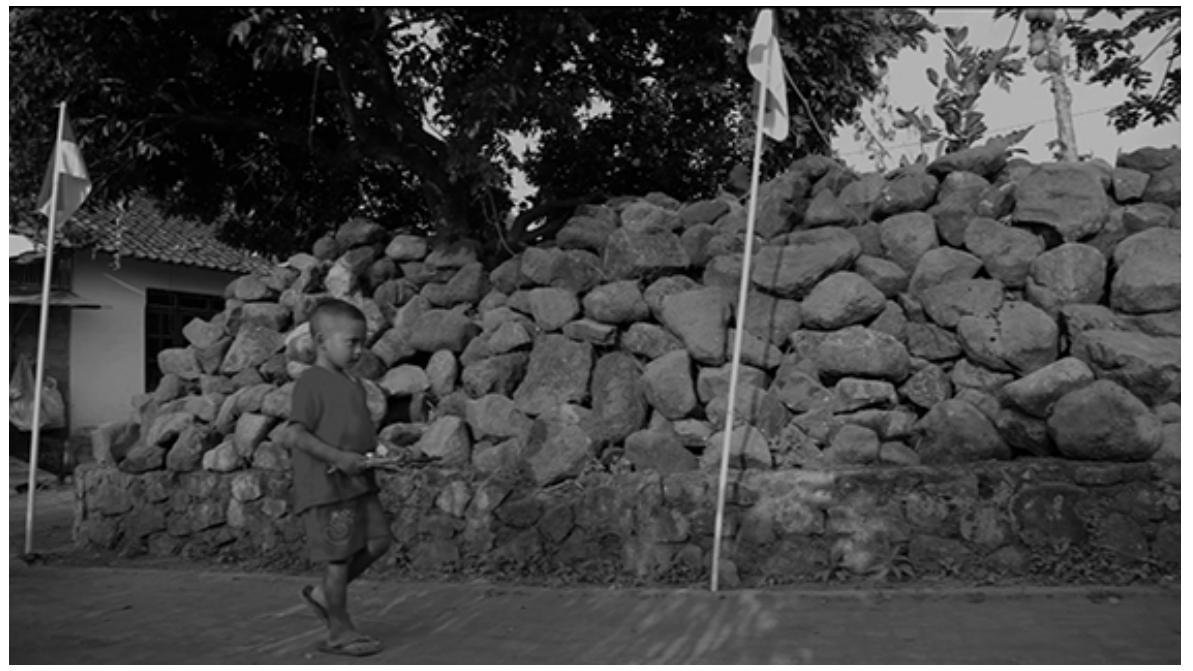

Gambar 3. Anak mengantar sesajen adalah pemandangan yang akrab di mata warga Kampung Tutup Ngisor 
Page $\mid 86$

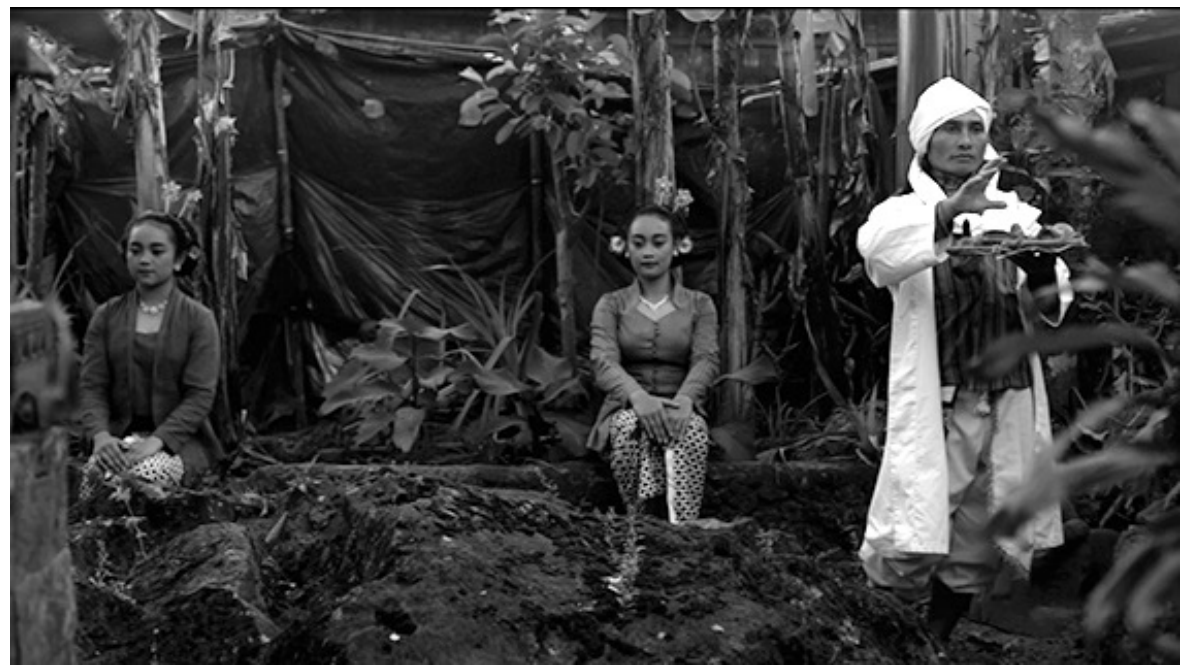

Gambar 4. Kostum para dhanyang seperti dijelaskan oleh Cipto Miharso

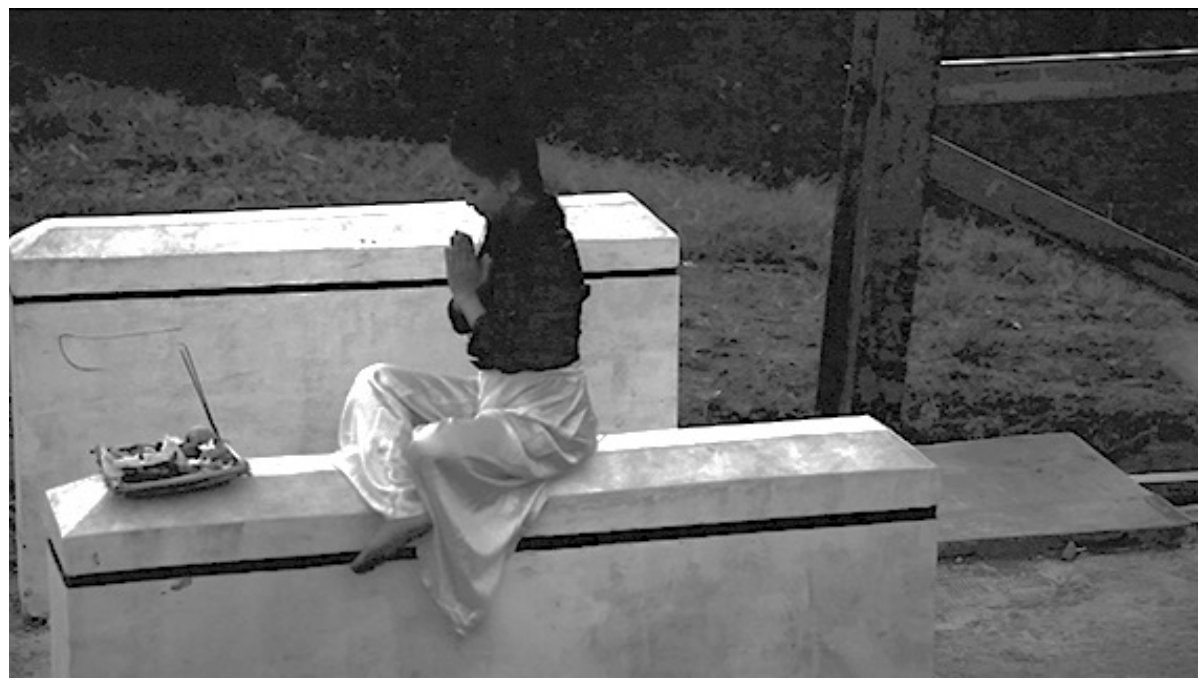

Gambar 5. Peri memperlihatkan rasa terima kasih untuk sesajen yang diberikan, lambang keharmonisan manusia dengan lingkungannya 


\section{KESIMPULAN}

Film ini menggunakan pendekatan sinema sebagai atraksi, yang untuk mendapat perhatian penonton menekankan kekuatan visualnya. Dalam kasus Tjipta Boedaja, para penari -mungkin secara naluriah- selalu mengaitkan pembuatan film mereka dengan produksi panggung yang sudah mereka jalan berpuluh-puluh tahun. Dalam kasus mereka, sebenarnya bermacam-macam tradisi gaya pertunjukan panggung yang mereka miliki telah mempersiapkan mereka untuk sinema atraksi maupun sinema narasi. Walau demikian, bagaimana mereka melakukan perencanaan dan pendekatan dalam cara produksi akan selalu mereka hubungkan dengan proses produksi dari tradisi pertunjukan yang telah biasa mereka lakukan itu.Mereka aktif mengeksplorasi cara yang paling cocok bagi mereka dalam membuat film.Evaluasi tentang cara mereka menangani produksi film, seperti evaluasi terakhir dari Trisantoso tentang keterlibatan setiap kru dari awal proses, juga berkaitan dengan praktik panggung mereka.

Film Tetangga adalah salah satu contoh eksplorasi mereka. Film tari tentu bukan film yang bisa dinikmati semua orang, tarian dalam film ini membuat jarak bagi penonton awam. Jika kita mengacu pada apa yang disarankan Adorno, tentu film yang berjarak adalah yang lebih ideal untuk menyampaikan pesan atau pernyataan, karena memaksa penonton menikmati film sambil berpikir. Penonton dari luar kampung yang menyaksikan harus selalu mengolah infomasi gambar alam dan tarian-tarian yang mereka lihat. Namun, sasaran utama film ini adalah warga Kampung Tutup Ngisor sendiri, yang sudah terbiasa menyaksikan pertunjukan tari tradisional tinggi seperti wayang orang, tarian kerakyatan yang biasa dilakukan di lapangan, serta tarian kontemporer. Bagi penonton ini, film Tetangga mudah dicerna dan memungkinkan mereka menikmatinya tanpa harus berpikir. Penghalang yang dibuat bagi mereka adalah gambar-gambar tempat yang familiar muncul dengan gambar yang dipoles serta diberikan musik, untuk memunculkan perasaan mistis, dan terian dari mahluk-mahluk ini sendiri ketika merespon sesajen yang mereka terima. Usaha ini kelihatannya cukup berhasil. Dalam beberapa pemutaran di pendopo kampung, anak-anak yang menonton bersama ibu atau nenek mereka berkali-kali meminta penjelasan mengenai apa yang mereka lihat di layar, dan orang tua yang mendampingi harus menjelaskan sosok-sosok itu. Ini tentu yang diharapkan agar terjadi dialog antara generasi yang satu kepada yang berikutnya.Untuk orang luar kampung, gambaran keindahan alam yang dipadukan dengan kerusakannya, diharapkan akan membantu memprovokasi mereka dan mengingatkan peran keberadaan mahluk-mahluk ini sebagai penjaga kelestarian alam.

\section{DAFTAR PUSTAKA}

Turner, G. (1988). Film as Social Practice. London: Routledge.

Adorno, T. (1981). Transparencies on Film. New German Critique (24/25), 199-205.

Brannigan, E. (2011). Dance Film: Choreography and the Moving Image. New York: Oxford University Press.

Hughes-Freeland, F. (2008). Embodied Communities: Dance Traditions and Change in Java. New York: Berghahn Books. 
Michaels, E. (1994). Bad Aboriginal Art: Tradition, Media and Technological Horizons. Minneapolis: University of Minnesota Press.

Moore, R. (2000). Savage Theory: Cinema as Modern Magic. Durham: Duke University Press.

Page | 88 Rony, F. T. (2006). The Photogenic Cannot Be Tamed: Margaret Mead and Gregory Bateson's Trance and Dance in Bali. Discourse, 28 (1), 5-27.

Morley, D. (2007). Media, Modernity and Technology: The Georaphy of the New. London: Routledge.

Lempert, W. (2012). Telling Their Own Stories: Indigenous Film as Critical Identity Discourse. The Applied Anthropologist, 32 (1), 23-32.

Ortner, S. (2013). Not Hollywood: Independent Film at the Twilight of the American Dream. Durham: Duke University Press.

John-Steiner, V. (2000). Creative Collaboration. New York: Oxford University Press.

Triyoga, L. S. (2010). Merapi dan Orang Jawa: Persepsi dan Kepercayaannya. Jakarta: Grasindo.

Gunning, T. (1990). The Cinema of Attractions: Early Film, Its Spectators and the AvantGarde. In T. Elsaesser, \& A. Barker (Eds.), Early Cinema: Space, Frame and Narrative (pp. 56-62). London: British Film Institute.

Keil, C. (2001). Early American Film in Transition: Story, Style, and Filmmaking, 19071913 . Madison: The University of Wisconsin Press.

Soedarsono. (1984). Wayang Wong: The State Ritual Dance Drama in the Court of Yogyakarta. Yogyakarta: Gadjah Mada University Press. 